\title{
The Effect of Unemployment and Low Quality Work Conditions on Work Values: Exploring the Experiences of Young Europeans
}

Emily Rainsford, William A. Maloney, Sebastian Popa

Email:

Rainsford.emily@ncl.ac.uk,

Adress:

Politics department Room W1.27, School of Geography, Politics and Sociology, 40-42 Great North Road, Newcastle University, NE1 7RU, UK.

Tel: +44(0)1912088824

Email: William.maloney@ncl.ac.uk

email: Sebastian.popa@ncl.ac.uk

Emily Rainsford is a Research Associate at Newcastle University working on youth political engagement and employment.

William A. Maloney is a Professor of Politcs and Head of School in Geography Politics and Sociology at Newcastle University and his research relates to civil society organisations and social capital.

Sebastian Popa is a lecturer in Comparative Politics and his research focuses on political behavior in a comparative perspective. 


\section{Abstract}

This article examines the impact that unemployment and low quality work conditions have on young adult's work values. Academic theory suggests that harsher economic conditions will make people prize extrinsic work values (income, security) more and intrinsic work values (creative, independent working conditions, autonomy) less. We apply this reasoning to study young Europeans' response to unemployment experience and low quality work conditions, expecting that those who have these experiences will value extrinsic values more and intrinsic work values less than those who do not have these experiences. Using the CUPESSE dataset of 18-35 year olds in eleven European countries, we do not find support for the effect of previous unemployment experience on intrinsic or extrinsic work values. However, when it comes to the effect of low quality work conditions there are mixed results. We find that one dimension of low quality work conditions — overqualification—does have a positive effect on extrinsic work values. Further, we find that age has a moderating effect: unemployment and low quality work conditions have a larger impact on the younger workers in our sample than their older counterparts.

Keywords: work values; working conditions; CUPESSE; overqualification; precarious; unemployment; young people

NOTE: We recognize financial support by the project Cultural Pathways to Economic SelfSufficiency and Entrepreneurship (CUPESSE; Seventh Framework Program of the European Union; Grant Agreement No. 613257). We thank Carolin Rapp, the guest editors, and one anonymous reviewer for their comments on earlier versions of this manscript. 
Structural changes within the labor market—including increased flexibility, high levels of unemployment, rising educational attainment levels, the changing nature of work itself (e.g., technological modernization and employment precarity), and the 2008 economic crisis—-have all had a significant impact on the ways in which people experience work (Cahuc et al. 2013; O'Reilly et al. 2015). These developments have had the most profound impact on those entering the labor market — the young (Dietrich 2012; Shore and Tosun 2017). Even though unemployment levels have recovered in many European countries after the crisis, youth unemployment levels remain stubbornly high (Cahuc et al. 2013; Oesingmann 2017; Tosun 2017).

Early unemployment experiences for young people can have various long-term effects both for society and the individual. Youth unemployment carries a significant economic cost, estimated at more than $€ 50$ billion in the European Union (EU) in 2011 (see Tosun 2017, 40). At the individual level, though, not only are young people more likely to experience unemployment " ... because their relative position in the queue for jobs deteriorates more easily when the growth for employment slows down" (Wolber 2007, 189), but unemployment can also have long-term scarring effects. The transition to the first sustainable job remains a critical and formative period that has consequences for the life chances of young people (Arnett 2000; and Ryan, 2001). Unemployment experience during this time increases the likelihood of being unemployed later in life, can decrease future salaries, send a negative signal to future employers, and lead to a loss in social networks and opportunity to develop important skills with a labor market currency (Dietrich 2012; Shore and Tosun 2017). Experience of unemployment during this formative time can directly influence young people's work values (Chow et al., 2014; Cemalcilar et al.; Gallie; Kalleberg and Marsden, this volume). 
Previous research has explored how societal changes influence work values across generations (Van den Broeck et al. 2010). For example, when times are tough during an economic crisis or in its immediate aftermath, or if individuals have experienced unemployment, then people tend to value job security and high incomes-extrinsic work values_ - over independent working and opportunities for personal development and growth— intrinsic work values (Kalleberg and Marsden, 2013). However, it is not only unemployment that shapes work values but also workplace and work-life experiences (Adkins and Naumann 2016). As Gallie (this volume) highlights, "while early socialization and education were generally important determinants of employment commitment and intrinsic reward values, difference in job quality are central for the explanation of country differences." In Europe, a growing concern for young people entering the labor market, and for policy-makers, is the quality of work (Cedefop 2018; Eurofound 2002).

Recent research in the UK characterized the labor market as resembling an hourglass with high quality jobs at the top, low quality ones at the bottom, and a hollowing out of the middle range occupations (Sissons 2011, 4). As Sissons $(2011,4)$ notes, this structural change means that highly skilled workers may find themselves getting "bumped down" the labor market, having to take on jobs that they are overqualified for. There are similar concerns regarding the skills mismatch beyond the UK. The EU also identified the skills mismatch as a critical issue following the 2008 economic crisis, with significant reductions in the number of jobs in certain sectors and employers finding it difficult to find people with the right skills for the jobs on offer (Cedefop 2018). ${ }^{\mathrm{i}}$ The OECD (OECD 1996, 132-33; cited in Curtain 2001,8 ) estimated that "men even up to the age of 28 may have problems in settling into stable work; for some who are early school leavers, the transition can last to age 35." The quality of work is thus a major concern for young people and policy-makers today and it is 
therefore important to understand how this experience affects what contemporary young people value in work.

The concept of quality of work is complex and the exact definition depends on whether it is assessed from the individual or societal perspective. The United Nations Economic Commission for Europe (UNECE; 2015, 13) defined quality of work as "the conditions and ethics of employment, monetary and non-pecuniary benefits, working time arrangements and work-life balance, employment security and social protection, skills development and training as well as work motivation and employment-related relationships." In this article we take an individual perspective and focus on the skills match and the type of contract the individual has, tapping into both the employment security and skills development aspects of the UNECE definition. ${ }^{\text {ii }}$

We advance previous research and contribute to the policy debate on quality of work by exploring not only the impact of unemployment on contemporary young European's work values but also the effect of low quality work. Both these experiences are highly likely to shape what young people value in work, and we aim to test the effects on intrinsic and extrinsic work values. To do this we draw on the CUPESSE dataset of 18-35 year olds in elven European countries (see Tosun et al. 2018), focusing only on the employed respondents as we are interested in the effect of working conditions on work values. Herein low quality work is defined as precarious or nonstandard jobs (casual, temporary, fractional work, or disadvantageous contracts $-e . g$. zero hoursand/or jobs in which workers believe that their qualifications are beyond the requirements of their current position (i.e., they considers themselves to be overqualified for the job). Drawing on Kalleberg and Marsden's (2013) problematic rewards thesis that suggest that those who have a secure and well paid job value intrinsic values more than those who do not we expect that people who have experience of 
unemployment or low quality working conditions will value extrinsic work values more and intrinsic work values less than those who do not have these experiences.

\section{Work Values and Young People}

As Gallie (this volume) notes, the last 50 years or so have witnessed, at times, lively debates surrounding the changing nature of work and its impact on the multidimensionality of work values. Lyons et al. $(2010,971)$ define work values "as generalized beliefs about the relative desirability of various aspects of work (e.g. pay, autonomy, working conditions), and workrelated outcomes (e.g. accomplishment, fulfillment, prestige)." Values are fundamental beliefs that people hold about right and wrong and in "the work setting ... are the evaluative standards relating to work or the work environment by which individuals discern what is right" or assess the importance of preferences (Wey Smola and Sutton 2002, 365-66). However, while these beliefs are normative they are not necessarily positive; that is, they relate to "what ought to be, rather than what is." (emphasis in original). Work values are central to explanations of workers' motivations, attitudes toward material and nonmaterial rewards, and work and career aspirations (see Kalleberg and Marsden, this volume). Following the introductory article in this volume (Kraaykamp et al.), our theoretical focus centers on the main, and most extensively studied, work value classification: intrinsic (stimulating work, individual autonomy, helping others, making a societal contribution) and extrinsic (job security and pay) (also see Kuron et al. 2015). Extrinsic work values can be viewed as a compensation for the general obligatory, unpleasant character of work (see also Halman and Müller 2006). While intrinsic values reflect intangible rewards related to the process of work (Deci and Ryan 2000).

There are many institutions and experiences that can shape (young) people's work values, including the varying economic and labor market conditions that different generations 
face, social background, parental employment contexts, parenting styles, school, the workplace, social networks, and so on (see Kirkpatrick Johnson and Mortimer, 2015). While early socialization is crucial in setting the foundations for values, values are not fixed or static; they can mutate as people's experiences and interactions with different institutions change. Youth is a particularly strong socialization period because it is formative, transformative, and transitional (Wyn and White 1997; and Lechner et al. 2017). Previous research has illustrated that the conditions and process of getting that first job after leaving education has long-term consequences for the value predispositions and life-chances of young people (Ryan 2001). Because of the current challenging and precarious situation for young people in the labor market, and given the importance of youth transitions to work, it is especially important to explore how experiences during this formative period shape work values.

\section{The Determinants of Work Values: The Quality of the Work Conditions} Kalleberg and Marsden $(2013,257)$ argue that the problematic rewards thesis predicts that people in highly paid and secure employment are much more likely to value intrinsic rewards rather than extrinsic rewards. Thus the unemployed, and those in search of low- or unskilled employment, will value a job that is adequately remunerated and relatively secure-i.e., extrinsic. The idea here is also linked to compensation. If basic material and security needs are not met or are under threat, then people's materialistic priorities are likely to increase (see Lechner et al. 2017: 54). In other words, the argument is that once workers' basic needs have been satisfied then their value preferences will shift to satisfying more aesthetic and selfactualizing needs (see also Kalleberg and Marsden, this volume).

In their study of changing work values in the United States between 1973 and 2006 Kalleberg's and Marsden's $(2013,267)$ results supported the problematic reward thesis. "When unemployment is high, jobs are scarce and so job security is more problematic, 
increasing the significance of having a job at all. Moreover, since wages are tied to jobs, attaining economic security also becomes more problematic during 'high-unemployment periods." Gallie et al.'s $(2012,819)$ complementary findings showed that when comparing people's job preferences between 1992 and 2006 the intrinsic quality of employment clearly increased. They argued that the key explanatory factors included "higher educational levels, higher skilled jobs and greater security in terms of pay and employment ... in a period of strong economic growth and rising prosperity."

For example, if young workers experience unemployment or enter the labor market in periods of economic and financial retrenchment and rising unemployment, they may tend to value more basic bread and butter aspects (extrinsic rewards) rather than the importance of personal development and quality of work opportunities (intrinsic rewards). While previous research has mainly focused on generational differences, and the effect of societal economic situations, Chow et al. (2014) illustrated in their analysis on young people in Canada that unemployment experiences early in the transition to adulthood have an immediate and longterm effect on work values. Accordingly, we examine the effects of previous unemployment experience on young people's work values. Our first hypotheses relating to the effects of unemployment on work values are:

H1a: Young people who have experienced unemployment will be more likely to value extrinsic work values compared to those who have not experienced unemployment.

H1b: Young people who have experienced unemployment will be less likely to value intrinsic work values than those who have not experienced unemployment.

As argued in the introduction to this article, the quality of working conditions is a significant issue for young people in the labor market today. However, the idea that work conditions influence work values is not new. For example, Kalleberg and Marsden (2013) 
and Gallie et al. (2012) both highlight that the conditions when an individual is seeking work and the type of employment that s/he secures - does it satisfy their basic needs, for example_influence individual job preferences and work values. Furthermore, Bokemeier and Lacy (1987) showed that current and past working conditions influence workers' attitudes to their current job and shape work values that, in turn, influence their behavioral patterns (Adkins and Naumann 2016). However, these scholars neither specifically addressed the position of young workers, nor did they investigate contract type or skills match. This article directly examines young workers and the impact of the quality of their work conditions on their work values. By doing this we make a significant and important contribution to the literature on work conditions and work values. Accordingly, we hypothesize that:

H2a: Young people who have experienced low quality work conditions will be more likely to value extrinsic work values compared to those who have not had such negative work experiences.

H2b: Young people who have experienced low quality work conditions will be less likely to value intrinsic work values compared to those who have not had such negative work conditions.

\section{Data, Measurement, and Methods}

For this analysis we use the CUPESSE dataset because it is a representative sample of 18-35 year olds across eleven countries in Europe (for more details about the dateset, see Tosun et al. 2018). Following from our theorietical focus on the effect of working conditions, we only perform the analysis on those who are employed, thus our sample size falls modestly from 11,989 in the full sample to 11,248 individuals in our working sample. 
In line with the argument presented in the introduction to this volume, we focus on intrinsic and extrinsic values. We move slightly beyond what is outlined in the introduction (Kraaykamp et al., this volume) and build an index of extrinsic and intrinsic values using the classification presented by Kuron et al. (2015). We use valuing "job security," "high income," "having time for leisure," and "balance work and other commitments" as our measures of extrinsic work values; and "working independently", "learning new things", "developing creativity", and "self-worth" to measure intrinsic work values. In both the intrinsic and extrinsic cases, we construct an additive index (i.e., the mean of the items) of items that are measured on a four-point scale with values between 1 "not at all important" to 4 "very important." iii

In the case of the intrinsic values index the Cronbach alpha is 0.7 , confirming that the items form an internally consistent scale. Although, in the case of the extrinsic value index the alpha values fall just below the accepted limits for internal consistency (0.6), it is important to note that this construct is based on our theoretical propositions (Kuron et al. 2015 and Kraaykamp et al., this volume). In addition to this, the correlations between each item and the extrinsic values index are very strong (between 0.65 and 0.7 ) pointing toward an acceptable level of internal consistency. Finally, in both cases the distribution of the indices are highly skewed to the right (extrinsic mean=3.4, $\mathrm{sd}=0.44$; intrinsic mean $=3.4, \mathrm{sd}=0.5$ ).

Turning to our main independent variable, we measure the effect of previous unemployment experience on work values by using a dichotomous variable that is given the value of 1 if respondents answered yes to the question: "Have you ever been unemployed for a period longer than 6 months?" and 0 otherwise. We conceptualize the quality of work using two indicators. The first captures job insecurity and is assigned the value 1 for those who do not have a permanent contract and 0 for those who have a permanent contract. The second variable captures the self-assessed match between the respondent's qualifications and their 
current job; this variable has three values: i) those who consider themselves overqualified for their current job; ii) those who believe they are underqualified for their current job; and iii) those who consider their job to be a good match with their qualifications. We use the latter as the reference category in our analysis.

We further control for a number of characteristics including the type of employment (being self-employed or not); the current economic situation of the respondents (being able to cover the basic costs of living, having moved out from the parental home, having responsibilities to care for others, or receiving financial support from parents); family financial background (if their family could afford extras beyond basic needs when the respondent was aged 14, for example, going on vacation) and a number of sociodemographic characteristics (age, education, gender, and migration background).

For the analysis we rely on a pooled regression model with fixed country effects. ${ }^{\text {iv }}$ All the independent variables are standardized and have values between 0 and 1 so that the coefficients can be easily compared and interpreted.

\section{Results and Discussion}

Table 1 summarizes the results of the analysis used to test our main theoretical expectations. ${ }^{\mathrm{v}}$ Surprisingly, we do not find support for the effect of previous unemployment experience on intrinsic or extrinsic work values. However, when it comes to the effect of low quality work conditions there are mixed results. On one hand, as expected, those who experience a mismatch between their qualifications and their current job, (i.e., believe they are overqualified) tend to place greater emphasis on extrinsic values (see model 1 in Table 1). On the other hand, contrary to our expectations, those who do not have a permanent contract place less weight on extrinsic values than those who have a permanent contract (see model 1 in Table 1). 
While all the findings outlined above are statically significant, the effects are nevertheless relatively small. This is not surprising given the distribution of the dependent variables. However, the low variation of the dependent variables increases the chances of Type II errors, making the detection of statically significant effects more difficult. Thus, we are confident that the effects are robust and not an artifact.

[Table 1 about here]

Given our surprising but interesting findings, we further explore why the effects of experiencing unemployment and not having a permanent contract differ from our theoretical expectation. In this regard, the explanation could be that the analysis is based on a sample of young adults. To be more specific, our general expectation is that the effect of both variables are substantially different for the younger respondents in our sample-remember our age range of 18-35 is more extensive than many other studies on young people. In other words, we suspect that age acts as a moderator for the effect of our independent variables on work values. In Table 2, we examine how the interactions between these two variables that do not behave as we expected with age can help to explain the level of extrinsic and intrinsic values.

[Table 2 about here]

We find that age has a statically significant interaction with not having a permanent contract for extrinsic values (See Table 2, model 3) and with unemployment experience in the case of intrinsic values (See Table 2, model 4). For ease of interpretation, we plot these effects. Thus, we note that that the difference in extrinsic work values between those who have and those who do not have a permanent contract diminishes with age (see Figure 1). This outcome is mostly because extrinsic values are more important for older individuals who are in precarious work situations compared to their younger counterparts. At the same time, those who have a permanent contract have the same level of extrinsic values irrespective of 
their age. However, for individuals who are around 35 years old, the difference in the level of extrinsic values depending on the type of contract is close to zero.

[Figure 1 about here]

In the case of intrinsic values (see Figure 2), we can see that the difference between those who have experienced unemployment and those who have not dissipates as people get older. In this case, there are two driving forces. On one hand, intrinsic values are more important for older individuals who have not experienced unemployment in comparison to their younger peers. At the same time, these values have become less important for older individuals who have experienced unemployment. Overall, these results confirm our main intuition that our sample of young workers is the main reason for our findings differing from previous research. In summary, in both the cases of intrinsic and extrinsic values, the differences depending on previous unemployment experience or current low quality work conditions (i.e., having no permanent contract) dissolve for individuals who are older.

[Figure 2 about here]

\section{Conclusion}

We set out to evaluate the extent to which previous unemployment experience and current work conditions influence the work values of young European adults. Previous research addressed the impact of unemployment on work values (Kalleberg and Marsden 2013), but we argue that by solely focusing on unemployment we fail to capture the full extent to which working conditions and experiences influence the development of work values for young people transitioning into the labor market. Given the important socializing experience of the workplace and its role in helping to shape work values (Adkins and Naumann 2016), and given the challenges young people face when entering the labor market (Cedefop 2018), we further argue that it is crucial to consider the quality of work conditions, in terms of precarious or nonstandard contracts and the skills match, as important work value shapers. 
We are also well aware that other profound contextual factors will play an important role in the development of young people's work values - for example, the differential impact of the 2007 economic crisis on young people in terms of both high youth unemployment and the diminishing quality of work.

In formulating our hypotheses our datum was the problematic rewards thesis. This theoretical proposition argues that under conditions of economic hardship people tend to place greater emphasis on extrinsic work values and are less concerned with intrinsic values (Kalleberg and Marsden 2013). Once we factor in the long-term scaring effect of unemployment experiences on young people (Chow et al. 2014), this led us to hypothesize that past unemployment experiences are associated with an increased emphasis on extrinsic values (H1a), while they would have a negative impact on the level of intrinsic values (H1b). Furthermore, we also expected the quality of working conditions to shape work values (Bokemeier and Lacy 1987), i.e., low quality work conditions lead to higher levels of extrinsic values (H2a) and lower levels of intrinsic values $(\mathrm{H} 2 \mathrm{~b})$. We chose to test our second hypothesis by focusing on the effect of not having a permanent contract or having a job that does not match our respondent's educational attainment and skills levels. These two indicators have been under-researched but contemporaneously they represent a significant challenge for young adults transitioning into the labor market (Curtain 2001; Sissons 2011). They are also increasingly of concern for policy-makers (Cedefop 2018).

Our analysis offers mixed evidence in support of our hypotheses, while also opening up further questions. We find support for the positive effect on extrinsic work values from one dimension of low quality work conditions, overqualification (H2a). Contrary to the same hypothesis $(\mathrm{H} 2 \mathrm{a})$, the other facet of low quality working conditions, not having a permanent contract, has a negative and statistically significant effect on the level of extrinsic values. Even more puzzling is the fact that in the case of unemployment experience, which has 
previously been found to be an important explanatory factory for both intrinsic and extrinsic work values, we do not find any statically significant effects for either type of work value.

These contradictory findings and the lack of effect in the case of the unemployment experience leads us to believe that this pattern of results is specific to young adults. In fact, once we consider the possible moderating effect of age, we notice that the effects do indeed relate directly to the younger segment our sample and start to dissipate in their older peers. To be more precise, for the older part of our sample the type of contract has no statically significant effect on extrinsic values. At the same time, the effect of unemployment experience is more in line with previous studies for the older individuals in the sample. In their case, we note that those who experienced unemployment do indeed seem to have lower levels of intrinsic values (H1b), while in the case of younger adults, we see the opposite pattern. The problematic rewards of work and need for satisfaction of material needs (Kalleberg and Marsden 2013) thus seem to be more or less problematic depending on the age of the worker.

To conclude, this paper has illustrated two important points. First, we see a significant moderating effect for age, where the effect of unemployment and precarious working conditions works differently depending on the age of the respondent. With this dataset we do not have the capacity to disentangle age or cohort effects, but what our analysis illustrates is that especially for a younger sample it is very important not to treat age just as any other control variable. Second, for young workers today the quality of the working conditions do shape their work values. They are more concerned with extrinsic work values, such as pay and security, if they consider themselves overqualified for their current job. Overqualification should be an issue for policy-makers and employers alike (Cefefop 2018). So far, the policy concern has primarily been the loss in productivity that overqualification leads to (Eurofound 2002). Our research illustrates that overqualification also has consequences for the individual 
and how they approach work, and this should be taken into consideration in the debate on overqualification. We also find, contrary to our expectation, that precarious working conditions are associated with a higher emphasis on intrinsic work values, such as personal development and independent working conditions. We must acknowledge that this pattern could be a consequence of self-selection effects. To be more specific, it could be the case that those who consider extrinsic values of security and pay to be less important are more likely to self-select into precarious jobs where they might satisfy their intrinsic needs to work independently and be creative. Both causal mechanisms are plausible and future research should test which causal path is more likely. Notwithstanding this finding, we argue that in this case, for young adults who are in the early stage of their "work" socialization process, the causal mechanism proposed in this article is more likely.

\section{References}

Adkins, Cheryl L., and Stefanie E Naumann. 2016. The value of achievement and responses to the work environment. Journal of Behavioral and Applied Management 3 (2): 14158.

Arnett, Jeffery Jensen. 2000. Emerging adulthood: A theory of development from the late teens through the twenties. American Psychologist 55 (5): 469-80.

Bokemeier, Janet L., and William B. Lacy. 1987. Job values, rewards, and work conditions as factors in job satisfaction among men and women. The Sociological Quarterly 28 (2): 189-204. 
Cahuc, Pierre, Stéphane Carcillo, Ulf Rinne, and Klaus F. Zimmermann. 2013. Youth unemployment in old Europe: The polar cases of France and Germany. IZA Journal of European Labor Studies. Available from http://ftp.iza.org/dp7490.pdf.

Cedefop, 2018. Insights into skill shortages and skill mismatch: Learning from Cedefop's European skills and jobs survey. Luxembourg: Publications Office. Available from http://data.europa.eu/doi/10.2801/645011.

Cemalcilar, Zeynep, Ekin Secinti, and Nebi Sumer. 2018. Intergenerational transmission of work values: A meta-analytic review. Journal of Youth and Adolescence 47 (8): $1559-1579$.

Cemalcilar, Zeynep, Jale Tosun, and Carsten Jensen. 2019. Gendered intergenerational transmission of work values? A country comparison. The ANNALS of the American Academy of Political and Social Science (this volume).

Chow, Angela, Harvey J. Krahn, and Nancy L. Galambos. 2014. Developmental trajectories of work values and job entitlement beliefs in the transition to adulthood. Developmental Psychology 50 (4): 1102-1115.

Curtain, Richard. 2001. Youth and employment: A public policy perspective. Development Bulletin 56 (October): 7-10.

Deci, Edward L., and Richard M. Ryan. 2000. The "what" and "why” of goal pursuits: Human needs and the self-determination of behavior. Psychological Inquiry 11 (4): $227-68$.

Dietrich, Hans. 2012. Youth unemployment in Europe: Theoretical considerations and empirical findings. Berlin: Friedrich-Ebert-Stiftung.

Eurofound. 2002. Quality of work and employment in Europe: Issues and challenges. Luxembourg: Office for official publications of the European communities. Available from https://www.eurofound.europa.eu. 
Gallie, Duncan. 2019. Research on work values in a changing economic and social context. The ANNALS of the American Academy of Political and Social Science (this volume).

Gallie, Duncan, Alan Felstead, and Francis Green. 2012. Job preferences and the intrinsic quality of work: The changing attitudes of British employees 1992-2006. Work, Employment and Society 26 (5): 806-21.

Halman, Loeck, and Hans Müller. 2006. Comparing orientations to work in African and European societies. International Journal of Comparative Sociology 47 (2): 117-43.

Kalleberg, Arne L., and Peter V. Marsden. 2013. Changing work values in the United States, 1973-2006. Social Science Research 42:255-70.

Kalleberg, Arne L., and Peter V. Marsden. 2019. Work values in the United States: Age, period and generational differences. The ANNALS of the American Academy of Political and Social Science (this volume).

Kirkpatrick Johnson, Monica, and Jeylan. T.Mortimer. 2015. Reinforcement or compensation? The effects of parents' work and financial conditions on adolescents' work values during the Great Recession. Journal of Vocational Behavior 87:89-100.

Kraaykamp, Gerbert, Zeynep Cemalcilar, and Jale Tosun. 2019. Transmission of work attitudes and values. Comparisons, consequences and implications. The ANNALS of the American Academy of Political and Social Science (this volume).

Kuron, Lisa K. J., Sean T. Lyons, Linda Schweitzer, and Eddy S. W. Ng. 2015. Millenials' work values: Differences across the school to work transition. Personnel Review 44:991-1009.

Lyons, Sean T., Chris A. Higgins, and Linda Duxbury. 2010. Work values: Development of a new three-dimensional structure based on confirmatory smallest space analysis. Journal of Organizational Behavior 31:969-1002. 
Oesingmann, Katrin. 2017. Youth unemployment in Europe. ifo DICE Report, ISSN 2511$7823,15(1): 52-55$.

O’Reilly, Jacquieline, Werner Eichhorst, András Gábos, Kari Hadjivassiliou, David Lain, Janine Leschke, Seamus McGuinness, Lucia Mýtna Kureková, Tiziana Nazio, Renate Ortlieb, Helen Russell, and Paola Villa. 2015. Five characteristics of youth unemployment in Europe: Flexibility, education, migration, family legacies, and EU Policy. SAGE Open (January-March): 1-19

Ryan, Paul. 2001. The school-to-work transition: A cross-national perspective. Journal of Economic Literature 39 (1): 34-92.

Shore, Jennifer and Jale Tosun. 2017. Assessing youth labour market services: Young people's perceptions and evaluations of service delivery in Germany. Public Policy and Administration. https://doi.org/10.1177/0952076717722192.

Sissons, Paul. 2011. The hourglass and the escalator: Labour market change and mobility. London: The Work Foundation. Available from https://www.researchonline.org.uk Sortheix, Florencia M., Angela Chow, and Katariina Salmela-Aro. 2015. Work values and the transition to work life: A longitudinal study. Journal of Vocational Behavior $89: 162-71$.

Tosun, Jale. 2017. Promoting youth emplyment through multi-organizational governance. Public Money and Management 37 (1): 39-46.

Tosun, Jale, José Arco-Tirado, Maurizio Caserta, Zeynep Cemalcilar, Marcs Freitag, Felix Hörisch, Carsten Jensen, Bernhard Kittel, Levente Littvay, Martin Lukes, et al. 2018. Perceived economic self-sufficiency: A country-and generation-comparative approach. European Political Science. https://doi.org/10.1057/s41304-018-0186-3. 
United Nations Economic Comission for Europe (UNECE). 2015. Handbook on measuring quality of employment. New York, NY: United Nations. Available from https://www.unece.org/stats/publications/stat_qua_emp.html.

Van den Broeck, Anja, Maarten Vansteenkiste, Willy Lens, and Hans De Witte. 2010. Unemployed individuals' work values and job flexibility: An explanation from expectancy-value theory and self-determination theory. Applied Psychology 59 (2): $296-317$.

Wey Smola, Karen, and Charlotte D.Sutton. 2002. Generational differences: Revisting generational work values for the new millennium. Journal of Organizational Behavior 23:363-82.

Wolber, Maarten. H. J. 2007. Patterns of labour market entry: A comparative perspective on school-to-work transitions in 11 European countries. Acta Sociologica 50 (3): 189210.

Wyn, Johanna, and Rob White. 1997. Rethinking youth. London: Sage 
Table 1:

Predicting extrinsic and intrinsic work values, main effects

\begin{tabular}{rcc}
\hline & Model 1: Extrinsic values & Model 2: Extrinsic values \\
\hline Intercept & $3.212(0.032)^{* *}$ & $3.271(0.037)^{* *}$ \\
No permanent contract & $-0.042(0.010)^{* *}$ & $0.012(0.011)$ \\
Experienced Unemployment & $0.016(0.010)$ & $-0.000(0.012)$ \\
Overqualified & $0.024(0.010)^{*}$ & $0.004(0.012)$ \\
Underqualified & $0.025(0.020)$ & $0.008(0.023)$ \\
Born in the country & $0.007(0.018)$ & $0.054(0.020)^{* *}$ \\
Can afford basics & $-0.001(0.010)$ & $-0.005(0.012)$ \\
Moved out & $-0.002(0.019)$ & $-0.028(0.022)$ \\
Age & $0.027(0.010)^{* *}$ & $0.000(0.012)$ \\
Caring responsibilities & $0.042(0.006)^{* *}$ & $0.018(0.007)^{*}$ \\
Self Employed & $-0.077(0.014)^{* *}$ & $-0.093(0.017)^{* *}$ \\
Parent support & $0.017(0.013)$ & $0.014(0.015)$ \\
Parents afforded extras & $0.004(0.014)$ & $0.031(0.016)$ \\
Secondary education & $0.028(0.015)$ & $0.016(0.018)$ \\
Tertiary education & $0.012(0.015)$ & $0.057(0.018)^{* *}$ \\
Female & $0.034(0.008)^{* *}$ & $0.050(0.010)^{* *}$ \\
Adj. $\mathrm{R}^{2}$ & 0.097 & 0.054 \\
Num. obs. & 9971 & 9971 \\
\hline
\end{tabular}

Notes: OLS regression coefficients with standard errors in parenthesis; $*$ denotes $p<0.05, * *$ denotes $p<0.01$ Country fixed effects are included in the models but not reported in the Table 1 (for full models see Appendix 1). 
Table 2:

Predicting extrinsic and intrinsic work values, interactions effects

\begin{tabular}{|c|c|c|}
\hline & $\begin{array}{l}\text { Model 3: Extrinsic values } \\
\text { (interactions) }\end{array}$ & $\begin{array}{l}\text { Model 4: Intrinsic values } \\
\text { (interactions) }\end{array}$ \\
\hline Intercept & $3.239(0.033)^{* * *}$ & $3.297(0.039)^{\text {*** }}$ \\
\hline $\begin{array}{r}\text { No permanent } \\
\text { contract }\end{array}$ & $-0.083(0.022)^{* *}$ & $-0.011(0.026)$ \\
\hline $\begin{array}{r}\text { Experienced } \\
\text { Unemployment }\end{array}$ & $-0.024(0.025)$ & $-0.063(0.029)^{*}$ \\
\hline Overqualified & $0.023(0.010)^{*}$ & $0.003(0.012)$ \\
\hline Underqualified & $0.026(0.020)$ & $0.008(0.023)$ \\
\hline Born in the country & $0.008(0.018)$ & $0.055(0.020)^{* * *}$ \\
\hline Can afford basics & $0.041(0.006)^{* *}$ & $0.018(0.007)^{*}$ \\
\hline Moved out & $-0.001(0.010)$ & $-0.005(0.012)$ \\
\hline Age & $-0.042(0.023)$ & $-0.068(0.027)^{*}$ \\
\hline $\begin{array}{r}\text { Caring } \\
\text { responsibilities }\end{array}$ & $0.027(0.010)^{* *}$ & $0.002(0.012)$ \\
\hline Self Employed & $-0.077(0.014)^{* *}$ & $-0.093(0.017)^{* *}$ \\
\hline Parent support & $0.018(0.013)$ & $0.015(0.015)$ \\
\hline $\begin{array}{r}\text { Parents afforded } \\
\text { extras }\end{array}$ & $0.003(0.014)$ & $0.030(0.016)$ \\
\hline Secondary education & $0.027(0.015)$ & $0.015(0.018)$ \\
\hline Tertiary education & $0.011(0.015)$ & $0.056(0.018)^{* *}$ \\
\hline Female & $0.033(0.008)^{* *}$ & $0.049(0.010)^{* *}$ \\
\hline Not permanent $X$ age & $0.069(0.034)^{*}$ & $0.038(0.040)$ \\
\hline $\begin{array}{r}\text { Unemployment } \mathrm{X} \\
\text { age }\end{array}$ & $0.062(0.036)$ & $0.100(0.042)^{*}$ \\
\hline Adj. $\mathrm{R}^{2}$ & 0.098 & 0.055 \\
\hline Num. obs. & 9971 & 9971 \\
\hline
\end{tabular}

Notes: OLS regression coefficients with standard errors in parenthesis; $*$ denotes $p<0.05, * *$ denotes $p<0.01$

Country fixed effects are included in the models but not reported in the Table 2 (for full models see Appendix 1). 
Figure 1:

Effect of not having a permanent contract conditional on age.

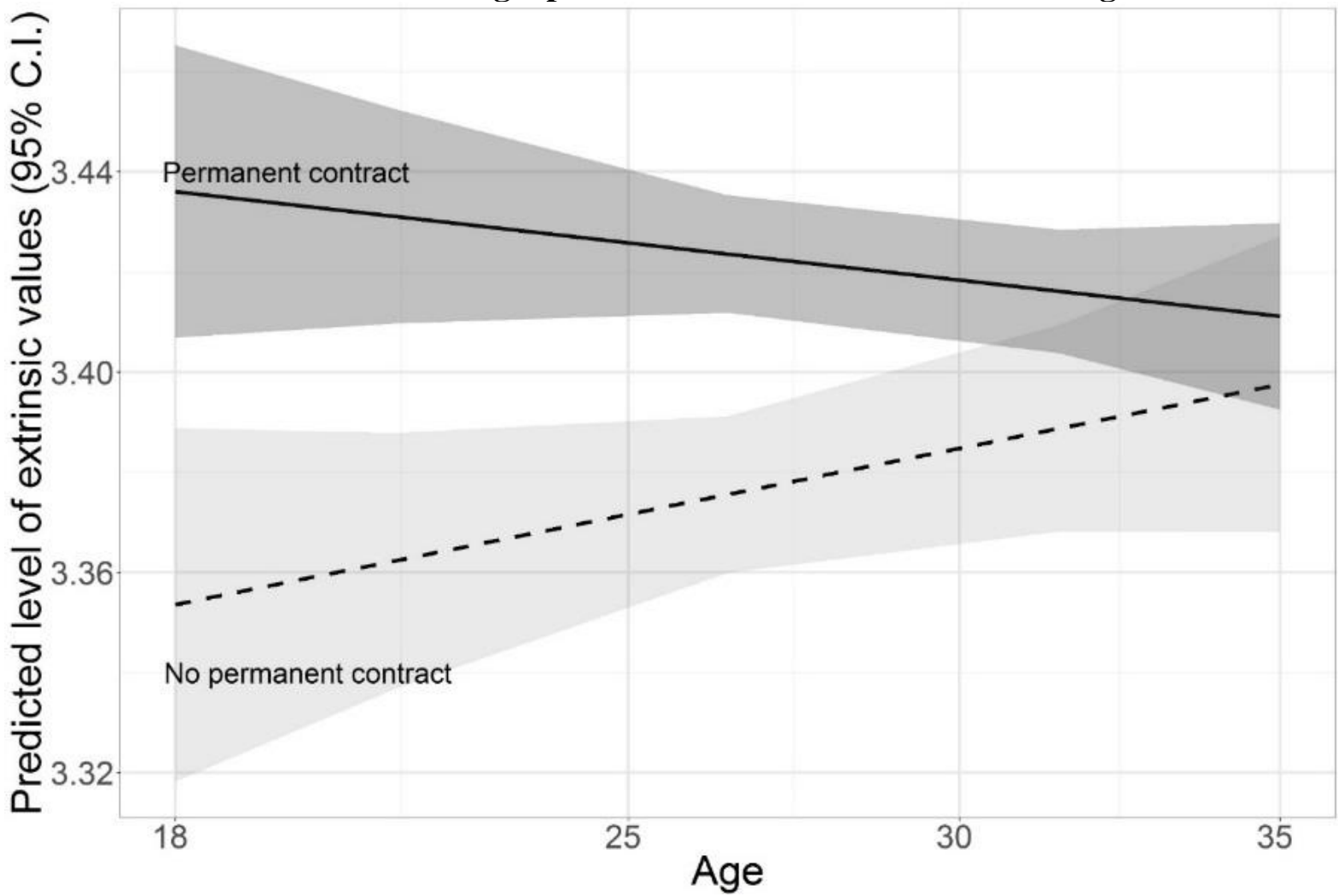

Figure 2: 


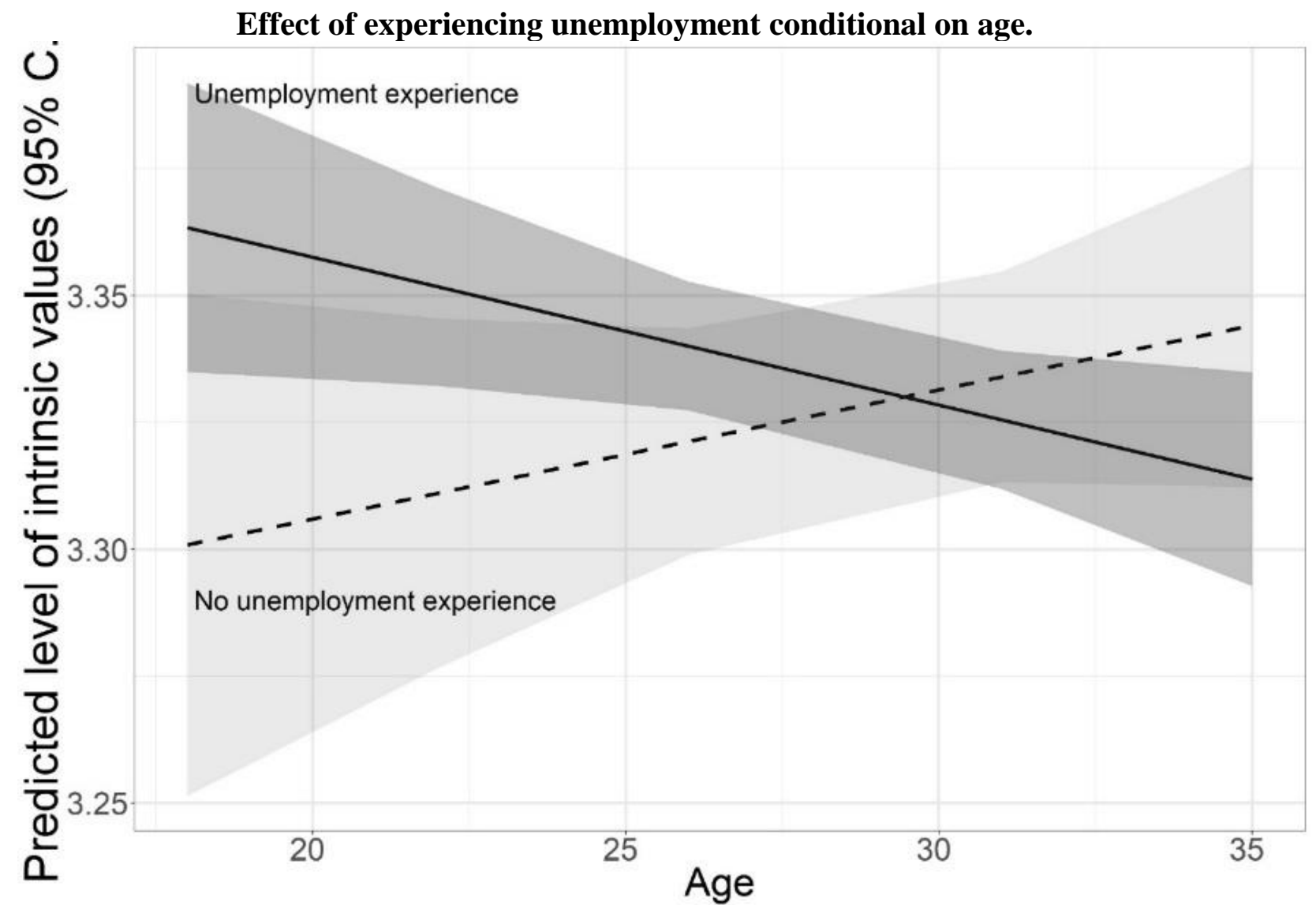




\section{Appendix 1: Models with country fixed effects reported.}

Table A1:

Predicting extrinsic and intrinsic work values, main effects

\begin{tabular}{|c|c|c|}
\hline & Model 1: Extrinsic values & Model 2: Extrinsic values \\
\hline Intercept & $3.212(0.032)^{* *}$ & $3.271(0.037)^{* *}$ \\
\hline No permanent contract & $-0.042(0.010)^{* *}$ & $0.012(0.011)$ \\
\hline Experienced Unemployment & $0.016(0.010)$ & $-0.000(0.012)$ \\
\hline Overqualified & $0.024(0.010)^{*}$ & $0.004(0.012)$ \\
\hline Underqualified & $0.025(0.020)$ & $0.008(0.023)$ \\
\hline Born in the country & $0.007(0.018)$ & $0.054(0.020)^{* *}$ \\
\hline Can afford basics & $-0.001(0.010)$ & $-0.005(0.012)$ \\
\hline Moved out & $-0.002(0.019)$ & $-0.028(0.022)$ \\
\hline Age & $0.027(0.010)^{* *}$ & $0.000(0.012)$ \\
\hline Caring responsibilities & $0.042(0.006)^{* *}$ & $0.018(0.007)^{*}$ \\
\hline Self Employed & $-0.077(0.014)^{* *}$ & $-0.093(0.017)^{* *}$ \\
\hline Parent support & $0.017(0.013)$ & $0.014(0.015)$ \\
\hline Parents afforded extras & $0.004(0.014)$ & $0.031(0.016)$ \\
\hline Secondary education & $0.028(0.015)$ & $0.016(0.018)$ \\
\hline Tertiary education & $0.012(0.015)$ & $0.057(0.018)^{* *}$ \\
\hline Female & $0.034(0.008)^{* *}$ & $0.050(0.010)^{* *}$ \\
\hline Czech Republic & $-0.171(0.023)^{* *}$ & $-0.158(0.026)^{* *}$ \\
\hline Denmark & $-0.306(0.024)^{* *}$ & $-0.143(0.028)^{* *}$ \\
\hline Germany & $-0.005(0.018)$ & $-0.147(0.021)^{* *}$ \\
\hline Greece & $0.146(0.023)^{* *}$ & $0.116(0.027)^{* *}$ \\
\hline Hungary & $0.112(0.022)^{* *}$ & $0.001(0.026)$ \\
\hline Italy & $0.078(0.025)^{* *}$ & $-0.040(0.030)$ \\
\hline Spain & $0.073(0.023)^{* *}$ & $0.005(0.027)$ \\
\hline Switzerland & $-0.129(0.025)^{* *}$ & $-0.099(0.029)^{* *}$ \\
\hline Turkey & $0.267(0.021)^{* *}$ & $0.151(0.025)^{* *}$ \\
\hline UK & $-0.005(0.018)$ & $-0.152(0.021)^{* * *}$ \\
\hline Num. obs. & 9971 & 9971 \\
\hline Adj. $\mathrm{R}^{2}$ & 0.097 & 0.054 \\
\hline
\end{tabular}

Notes: OLS regression coefficients with standard errors in parenthesis; ${ }^{*}$ denotes $p<0.05,{ }^{*} *$ denotes $p<0.01$ 


\section{Appendix 2}

Table A2:

Predicting extrinsic and intrinsic work values, interactions effects

\begin{tabular}{|c|c|c|}
\hline & $\begin{array}{l}\text { Model 4: Extrinsic values } \\
\text { (interactions) }\end{array}$ & $\begin{array}{l}\text { Model 5: Intrinsic values } \\
\text { (interactions) }\end{array}$ \\
\hline Intercept & $3.239(0.033)^{* *}$ & $3.297(0.039)^{* *}$ \\
\hline No permanent contract & $-0.083(0.022)^{* *}$ & $-0.011(0.026)$ \\
\hline $\begin{array}{r}\text { Experienced } \\
\text { Unemployment }\end{array}$ & $-0.024(0.025)$ & $-0.063(0.029)^{*}$ \\
\hline Overqualified & $0.023(0.010)^{*}$ & $0.003(0.012)$ \\
\hline Underqualified & $0.026(0.020)$ & $0.008(0.023)$ \\
\hline Born in the country & $0.008(0.018)$ & $0.055(0.020)^{* *}$ \\
\hline Can afford basics & $0.041(0.006)^{* *}$ & $0.018(0.007)^{*}$ \\
\hline Moved out & $-0.001(0.010)$ & $-0.005(0.012)$ \\
\hline Age & $-0.042(0.023)$ & $-0.068(0.027)^{*}$ \\
\hline Caring responsibilities & $0.027(0.010)^{* *}$ & $0.002(0.012)$ \\
\hline Self Employed & $-0.077(0.014)^{* *}$ & $-0.093(0.017)^{* *}$ \\
\hline Parent support & $0.018(0.013)$ & $0.015(0.015)$ \\
\hline Parents afforded extras & $0.003(0.014)$ & $0.030(0.016)$ \\
\hline Secondary education & $0.027(0.015)$ & $0.015(0.018)$ \\
\hline Tertiary education & $0.011(0.015)$ & $0.056(0.018)^{* *}$ \\
\hline Female & $0.033(0.008)^{* *}$ & $0.049(0.010)^{* *}$ \\
\hline Czech Republic & $-0.170(0.023)^{* *}$ & $-0.157(0.026)^{* *}$ \\
\hline Denmark & $-0.304(0.024)^{* *}$ & $-0.141(0.028)^{* *}$ \\
\hline Germany & $-0.003(0.018)$ & $-0.146(0.021)^{* *}$ \\
\hline Greece & $0.147(0.023)^{* *}$ & $0.116(0.027)^{* *}$ \\
\hline Hungary & $0.113(0.022)^{* *}$ & $0.003(0.026)$ \\
\hline Italy & $0.078(0.025)^{* *}$ & $-0.040(0.030)$ \\
\hline Spain & $0.074(0.023)^{* *}$ & $0.006(0.027)$ \\
\hline Switzerland & $-0.128(0.025)^{* * *}$ & $-0.099(0.029)^{* *}$ \\
\hline Turkey & $0.267(0.021)^{* *}$ & $0.152(0.025)^{* *}$ \\
\hline UK & $-0.003(0.018)$ & $-0.150(0.021)^{* *}$ \\
\hline Not permanent $X$ age & $0.069(0.034)^{*}$ & $0.038(0.040)$ \\
\hline Unemployment $\mathrm{X}$ age & $0.062(0.036)$ & $0.100(0.042)^{*}$ \\
\hline Adj. $R^{2}$ & 0.098 & 0.055 \\
\hline Num. obs. & 9971 & 9971 \\
\hline
\end{tabular}

Notes: OLS regression coefficients with standard errors in parenthesis; $*$ denotes $p<0.05$, ** denotes $p<0.01$ 


\footnotetext{
${ }^{\mathrm{i}}$ The European Skills Jobs Survey found that four in ten adult employees consider themselves overqualified for their work, and the same proportion of employers said that it was difficult to find employees with the appropriate skills for the job (Cedefop 2018).

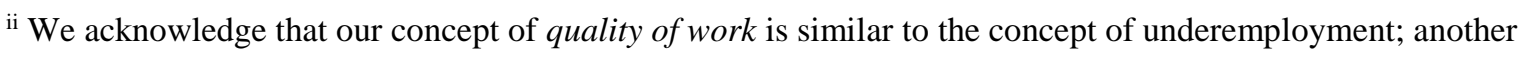
very important concept in the youth labor market. However, underemployment relates to, on one hand, the skills match, or overqualification, that overlaps with our concept; and on the other hand, whether the employee has the opportunity to work as many hours as they like, e.g., they work part time and they want to work part time. This is a rather economic concept relating to the productivity of the worker; we are more interested in the experience of work, and how the quality of this experience affects what the worker values in work.

iii This theoretical distinction is also confirmed by a factor analysis using promax rotation. Nevertheless, adopting a restrictive conceptualization that only identifies high income and job security as reflecting extrinsic values; while intrinsic values are only reflected by working independently and developing creativity (Cemalcilar, Jensen, and Tosun, this volume), yields the same substantive conclusions.

${ }^{\text {iv }}$ Using clustered standard errors is not necessary given that we do not have any variables that are at the country level. Still using such a model yields the exact same conclusions.

${ }^{v}$ Due to item nonresponse the number of cases drops from 11,284 to 9,971.
} 